\title{
ULNAR COMPRESSION NEUROPATHY : AN UNCOMMON COMPLICATION IN SURGICAL REPAIR OF PRESSURE ULCERS
}

\author{
By Mahendra Nath, M.B., B.S., M.S. and Robert G. Taylor, M. D. \\ Department of Physical Medicine $\mathcal{E}$ Rehabilitation, University of California at Davis, \\ Sacremento Medical Center, Sacremento, Cal., U.S.A.
}

Abstract. Four patients with paraplegia at levels $\mathrm{T}_{3}$ or below were required to remain in the prone position for periods of 3 to 5 weeks following plastic surgical repair of their pressure ulcers. Serial nerve conduction studies permitted early identification of compromise of ulnar nerve function prior to onset of symptoms. These objective findings are helpful in encouraging patients to protect the nerve, thus preventing palsy.

Key words: Decubitis ulcers; Elbow; Nerve compression syndrome; Neural conduction; Paraplegia; Ulnar nerve.

\section{Introduction}

For the spinal cord injured persons the functional competence in the upper extremities is the key to their independence. Their vulnerability to pressure sore and its prevention is quite a formidable task. Many of these pressure sores are amenable to surgical repair. However, positioning required to avoid pressure on the operative site can often produce complications in remote areas. Following surgical repair of ischial and sacral ulcers, it is common practice to maintain the patient in the prone position to avoid pressure to the operative site. During waking hours patients in the prone position maintain the elbows in the fully flexed position for many hours to prop their heads on the hands. This manoeuvre adds further pressure to the ulnar nerve in the condylar tunnel as it is pressed against the bed, supporting the weight of the head and trunk. Because of its very significant role in the function of the hand, loss of ulnar nerve function in a paraplegic could reduce him to a life of dependence. This would be an inexcusable reduction of the patient's fuctional ability.

\section{Method}

Serial studies of ulnar nerve were performed on four patients with paraplegia where prone positioning was required following surgical repair of pressure sores. Patients with spinal cord lesion at level T 2 or below were selected to exclude patients that could have lost some function of the intrinsic muscles of the hand as a result of injury at higher levels. Motor nerve conduction studies were performed to evaluate function of the ulnar nerve for the segments: Below elbow to wrist $(\mathrm{BE}-\mathrm{W})$, above elbow to wrist (AE-W) and the across elbow segment (AE-BE). Studies were performed using surface electrode techniques with pick-up from abductor digit minimi and commercially available electromyographic equipment.

Since we were aware of the possibility that ulnar nerve function could be

Address for correspondence: Mahendra Nath, M.B., B.S., M.S. (Ortho. Surg.), Southwest Regional Spinal Injury Center, Good Samaritan Hospital, I033 E. McDowell Road, Pheonix, Arizona 85006. 
compromised as a result of prone lying, all patients were supplied with padded elbow protectors. In addition, none of them had general anaesthesia for their surgery, thus reducing the risk of ulnar nerve damage from positioning on the operating table. No patient had complaints of paraesthesia, numbness or any other clinical symptom that would suggest compromise of ulnar nerve function. Two patients showed no change in any of the parameters measured. In spite of our concern and precautions for protecting the ulnar nerve and the absence of symptoms two patients developed changes that indicated some compromise of ulnar nerve function and are reported in detail.

\section{Case reports}

Case I: A 3I-year-old male paraplegic, motor and sensory complete at $\mathrm{T}_{3}$ level since a gunshot injury 9 years earlier. Prone and side lying positioning was required following plastic surgery for repair of sacral and ischial pressure ulcerations. No complications in wound healing occurred and the patient discontinued the prone positioning on the 28th day. During the time in the prone position the patient had no motor or sensory complaints referable to the ulnar nerve.

Case 2: A 30-year-old male paraplegic, motor and sensory complete at $\mathrm{T} 9$ level following a vehicular accident 5 years ago. Prone lying was required following surgical repair of left ischial and left trochanteric ulcers on the same day. Prone positioning was discontinued by day 30. During the time in the prone position the patient had no motor or sensory symptoms referable to the ulnar nerve.

\section{Results}

Studies of ulnar nerve function prior to surgery were not available on these patients (Table I). Case I had developed definite slowing of conduction velocity

TABLE I

\begin{tabular}{|c|c|c|c|c|c|c|c|c|c|c|}
\hline \multirow{3}{*}{$\begin{array}{l}\text { Days } \\
\text { Post- } \\
\text { surgery }\end{array}$} & \multirow{2}{*}{\multicolumn{2}{|c|}{$\begin{array}{c}\text { Distal } \\
\text { latency } \\
\mathrm{m} / \mathrm{sec}\end{array}$}} & \multirow{2}{*}{\multicolumn{2}{|c|}{$\begin{array}{l}M \text { wave } \\
\text { amplitude } \\
\text { mV }\end{array}$}} & \multicolumn{6}{|c|}{ Ulnar motor nerve conduction velocity $(\mathrm{m} / \mathrm{sec})$} \\
\hline & & & & & \multicolumn{2}{|c|}{ BE-W } & \multicolumn{2}{|c|}{$A E-W$} & \multicolumn{2}{|c|}{$\mathrm{AE}-\mathrm{BE}$} \\
\hline & Right & Left & Right & Left & Right & Left & Right & Left & Right & Left \\
\hline \multicolumn{11}{|l|}{ Case I } \\
\hline $\begin{array}{l}23 \\
28\end{array}$ & $\begin{array}{l}3 \cdot 2 \\
\text { Off } p 1\end{array}$ & $\begin{array}{c}3.6 \\
\text { one pc }\end{array}$ & $\begin{array}{r}\text { IO } \\
\text { ition }\end{array}$ & 9 & 56 & 63 & 46 & 57 & 27 & 43 \\
\hline $\begin{array}{l}3 \mathrm{I} \\
7 \mathrm{I}\end{array}$ & $\begin{array}{l}5 \cdot 2 \\
3 \cdot 8\end{array}$ & $\begin{array}{l}4.5 \\
3.8\end{array}$ & $\begin{array}{l}7 \\
6\end{array}$ & $\begin{array}{r}8 \\
15\end{array}$ & $\begin{array}{l}48 \\
46\end{array}$ & $\begin{array}{l}54 \\
6 \mathrm{I}\end{array}$ & $\begin{array}{l}42 \\
43\end{array}$ & $\begin{array}{l}48 \\
54\end{array}$ & $\begin{array}{l}33 \\
35\end{array}$ & $\begin{array}{l}40 \\
4 \mathrm{I}\end{array}$ \\
\hline \multicolumn{11}{|l|}{ Case 2} \\
\hline $\begin{array}{r}3 \\
17 \\
30\end{array}$ & $\begin{array}{l}2 \cdot 0 \\
3 \cdot 4 \\
\text { Off pr }\end{array}$ & $\begin{array}{c}2 \cdot 0 \\
3 \cdot 0 \\
\text { one pc }\end{array}$ & $\begin{array}{r}15 \\
7 \\
\text { ition }\end{array}$ & $\begin{array}{l}20 \\
10\end{array}$ & $\begin{array}{l}53 \\
53\end{array}$ & $\begin{array}{l}58 \\
64\end{array}$ & $\begin{array}{l}54 \\
60\end{array}$ & $\begin{array}{l}57 \\
54\end{array}$ & $\begin{array}{l}57 \\
54\end{array}$ & $\begin{array}{l}56 \\
43\end{array}$ \\
\hline 38 & $2 \cdot 7^{2}$ & $3 \cdot 2$ & 20 & I5 & 60 & 62 & 58 & 55 & 55 & 43 \\
\hline 73 & $2 \cdot 0$ & $2 \cdot 5$ & I 2 & I4 & 63 & 74 & 57 & 65 & 45 & 50 \\
\hline
\end{tabular}

$\mathrm{BE}-\mathrm{W}$, below elbow to wrist; $\mathrm{AE}-\mathrm{W}$, above elbow to wrist; $\mathrm{AE}-\mathrm{BE}$, segment across elbow. I $6 / 4 \mathrm{C}$ 
for the segment $\mathrm{AE}-\mathrm{BE}$ on the right at the time of the initial study. Distal latencies became prolonged and $M$-wave amplitudes had decreased by the time of the second study and returned to normal and near original values by the third study.

In Case 2 the changes were considerably more subtle with no values outside the normal ranges. These changes would have been recognised except for serial studies. Velocity decreased for the segment AE-BE on the left side and returned almost to original values by the third study. The velocity changes for the other segments were of no significant help. As with Case I, there were sublte changes in the distal latencies and the $M$ wave amplitudes decreased by 50 per cent bilaterally. These values returned to near original values for the fourth study.

\section{Discussion}

The elbow region is the most common site at which the ulnar nerve is vulnerable. The best known and most studied ulnar nerve lesions are those which accompany bony abnormality or trauma at the elbow, e.g. fractures of the lower end of the hemerus, fractures of the medial epicondyle and elbow dislocation (Watson-Jones, 1930). Other factors implicated are 'traction neuritis' due to increased valgus deformity (Brickner, 1924), 'friction neuritis' due to irregularity of the ulnar groove (Sheldon, I92I), subluxation of the ulnar nerve in its groove due to lax ligaments (Platt, I926), ganglion, tumours, lacerations, etc.

The significance of the anatomic arrangement of the ulnar nerve at the elbow exposing it to pressure was recognised by Weir Mitchell (I872) more than a century ago. That the ulnar nerve is vulnerable to physiologic compresssion was a fact known to Gowers (I892) when he described 'ulnar nerve sleep palsy'. Budinger in 1894 described ulnar nerve palsies as a result of malpositioning at the operating table and since then sporadic reports have appeared describing the importance of proper positioning of the unconscious patient (Gurdjian, I93 I Clausen, 1942; Slocum, I948; Dhuner, 1950). Waltman (1930) while reporting on the causes of ulnar nerve lesions in 300 cases described a series of chronically bedridden patients who developed ulnar nerve lesions as a result of compression of the nerve against the epicondyle as the patient attempted to prop himself up in bed.

Vanderpool et al. (I968) described a patient who developed compression neuropathy of the ulnar nerve at the elbow during the period of attachment for a pectoral skin flap to the hand, emphasisng the role of flexion at the elbow.

In 1958 Feindel and Stratford described the narrowing of the cubital tunnel as the elbow is flexed, secondary to an elevation of floor of the tunnel and tightness of the inelastic roof. In 1957 Osborne described a band of fibrous tissue bridging the two heads of the flexor carpi ulnaris, compressing the ulnar nerve in the cubital tunnel, as it runs between the two heads of origin of the flexor carpi ulnaris muscle. He pointed out that the band is slack in full extension. However, as the elbow is flexed it starts to tighten at $45^{\circ}$ of flexion and becomes taut with $90^{\circ}$ of flexion.

Our patients were required to remain in the prone position to avoid pressure to the surgical sites following repair of their pressure ulcers. In order for the patient to be active in bed, while in the prone position, the elbows are maintained in the flexed position for long periods of time. Apfelberg and Larsen (1973) described the compromise of the condylar canal $2.5 \mathrm{~mm}$ smaller, with elbow flexion, in addition to the compromise of the cubital tunnel from elbow flexion.

Both of the above mentioned mechanisms would exist in such patients and in addition the weight of the head and trunk added additional external pressure to 
the ulnar nerve in the condylar canal, as it was pressed against the bed. This combination of factors is certainly capable of producing compression neuropathy.

Wadsworth (1974) stated that it is doubtful if even minor compression palsy of the ulnar nerve, at the elbow, ever recovers fully. An example of this is shown by the lack of recovery for the right ulnar nerve in Case I. Surgical release of the nerve for this patient was discussed and refused by the patient. In contrary argument Eisen and Danon (1974) state that mild or early lesions will recover spontaneously as was seen in Case 2. The absence of clinical symptoms in our patient should not be accepted as reinforcing Brooks' (I963) argument that motor fibres can be significantly involved while sensory fibres are completely spared.

\section{Summary}

The main value of the electrodiagnostic testing in our patients was to detect early evidence of damage to the ulnar nerve. Although the patients frequently complained or joked about the need for the test, it focused their attention on our concern that the nerve might be damaged. As a result, whenever objective evidence of altered function was demonstrated patients and staff devoted more serious attention to avoid the potentially damaging positions of elbow flexion and propping on the elbows. It would appear from the findings in these cases that evidence of change in function is a much better indicator of damage than rigid criterion for normal (Eisen and Danon, 1974; Bhala, 1976). It is suggested that serial motor nerve conduction studies are of value in detecting evidence of early damage to peripheral nerves, specifically the ulnar nerve, and if detected in time can prevent irreversible damage.

\section{RÉSUMÉ}

4 patients atteints de paraplégie (lésion médullaire au niveau de $\mathrm{D}_{3}$ ou inférieur) ont été maintenu en pronation pour une période de 3 à 5 remaines après correction chirurgicale d'ulcères de decubitus.

Des mesures répétées de conduction nerveuse ont permis le diagnostic précoce d'atteinte fonctionnelle nerveuse cubitale avant l'apparition de symptomes. Les signes objectifs précoces permettent de protéger le nerf et d'enter ainsi la paralysie.

\section{ZUSAMMENFASSUNG}

Vier Patienten mit Rückenmarksbeschadigungen auf Höhe $\mathrm{T}_{3}$ oder weiter kauda haben Drucknekrosen bekommen. Diese wurden chirurgisch geschlossen. Während der drei- bis fünfwöchigen Heilungsperioden mussten die Patienten auf dem Bauch liegen leiger. Serienweise Messungen der Reizgeschwindigkeit des N. Ulnaris erlaubten, vor Symptomenanfang, die frühe Feststellung eines Nervengefährdens. Diese objectiven Befunde maklen die Patienten, den N. Ulnaris zu schützen, um eine Lähmung zu verkindern.

\section{REFERENCES}

Apfelberg, D. B. \& Larson, S. J. (1973). Dynamic anatomy of the ulnar nerve at the elbow. Plastic \& Reconstructive Surgery, 5I, 76-8I.

Bhala, R. P. (1976). Electrodiagnosis of ulnar nerve lesions at the elbow. Arch. Phys. Med. Rehabil., 57, 206-2I 2.

BRICKNER, W. M. (I924). Late ulnar palsy following elbow fracture in the adult. F. Bone E Foint Surg., 6, 477.

Brooks, D. M. (I963). Nerve compression syndromes. F. Bone E foint Surg., 45B, 445.

Budinger, K. (I975). Quoted from: Cameron, M. G. P. \& STewart, O. J. (I975). Ulnar nerve injury associated with anaesthesia. Can. Anaesth. Soc. F., 22, 253-264.

Clausen, E. G. (1942). Postoperative ('anaesthetic') paralysis of brachial plexus. Surgery, 12, 933 . 
Dhuner, K. G. (1950). Nerve injuries following operations. Anaesthesiology, II, 289-293.

Eisen, A. \& Danon, J. (1974). The mild cubital tunnel syndrome. Neurology, 24, 608-613.

Feindel, W. \& StRATfoRd, J. (1958). Cubital tunnel compression in tardy ulnar palsy Can. Med. Assoc. F., 78, $35 \mathrm{I}-353$.

Gowers, W. R. (I892). A Manual of Diseases of the Nervous System, 2nd. ed., Vol I. Churchill, London.

GurdjIAN, E. S. (I93I). Traumatic ulnar neuritis due to strapping of the elbow and the forearm to the operating table. F. Amer. Med. Assoc., 96, 944.

OsBorne, G. V. (1957). The surgical treatment of tardy ulnar neuritis. F. Bone E foint Surg., 39B, 782 .

Platt, H. (I926). The pathogenesis of traumatic neuritis of the ulnar nerve in the postcondylar groove. Brit. F. Surg., 13, 409-431.

Sheldon, W. D. (I92I). Tardy paralysis of the ulnar nerve. Medical Clinics of North America, 5, 499 .

Slocum, H. C., O’NeAl, K. C. \& Allen, C. R. (I948). Neurovascular complications from malposition on the operating table. Surg. Gynec. E Obst., 86, 720.

Vanderpool, D. W., Chalmers, J., Lamb, D. W. \& Whiston, T. B. (I968). Peripheral compression lesions of the ulnar nerve. F. Bone E Foint Surg., 50B, 792-803.

Wadsworth, T. G. (1974). The cubital tunnel and external compression syndrome. Anaesthesia and Analgesia: Current Researches, 53, 303-308.

Watson-Jones, R. (1930). Primary nerve lesions in injuries of the elbow and wrist. $\mathcal{F}$. Bone E Foint Surg., 12, I2 I-I 40.

Weir, Mitchell, S. (I972). Injuries of Nerves and Their Consequences. J. B. Lippincott Co., Philadelphia.

Woltman, H. W. (1930). Pressure as a factor in the development of neuritis of the ulnar and common peroneal nerves in bedridden patients. Amer.F. Med. Soc., 179, 528-532. 